View PDF Version Previous Article Next Article

\title{
Pinhole-free perovskite films for efficient solar modules $\perp$
}

W. Qiu *ab, T. Merckx ${ }^{a}$, M. Jaysankar ${ }^{a c}$, C. Masse de la Huerta ${ }^{a}$, L. Rakocevic ${ }^{a c}$, W. Zhang ${ }^{d}$, U. W. Paetzold ${ }^{a}$, R. Gehlhaar ${ }^{a}$, L. Froyen ${ }^{b}$, J. Poortmans ${ }^{a c}$, D. Cheyns ${ }^{a}$, H. J. Snaith ${ }^{d}$ and P. Heremans *ac

aIMEC, Kapeldreef 75, Heverlee,B-3001,Belgium.E-mail: Weiming.Qiu@imec.be;

Paul.Heremans@imec.be

${ }^{b}$ MTM, KU Leuven, Heverlee, Belgium

${ }^{c}$ ESAT, KU Leuven, Heverlee, Belgium

${ }^{d}$ Dept. Physics, University of Oxford, UK

Received 8th December 2015 , Accepted 5th January 2016

First published on the web 5th January 2016

We report on a perovskite solar module with an aperture area of $4 \mathrm{~cm}^{2}$ and geometrical fill factor of $91 \%$. The module exhibits an aperture area power conversion efficiency (PCE) of 13.6\% from a current-voltage scan and $12.6 \%$ after 5 min of maximum power point tracking. High PCE originates in pinholefree perovskite films made with a precursor combination of $\mathrm{Pb}\left(\mathrm{CH}_{3} \mathrm{CO}_{2}\right)_{2} \cdot 3 \mathrm{H}_{2} \mathrm{O}, \mathrm{PbCl}_{2}$, and $\mathrm{CH}_{3} \mathrm{NH}_{3} \mathrm{I}$.

\section{Broader context}

Recently, significant progress has been made in organometallic halide perovskite solar cell research, boosting the record certified power conversion efficiency (PCE) up to $20.1 \%$. 
However, most high PCEs of perovskite solar cells are recorded on small areas, typically around $0.1 \mathrm{~cm}^{2}$. Therefore, it is of great importance to demonstrate high efficiency large area perovskite solar modules. One of the key challenges for up-scaling perovskite solar cells is to fabricate pinhole-free, uniform perovskite films on large areas, using scalable deposition techniques. In this work, we developed a new precursor system of $\mathrm{Pb}\left(\mathrm{CH}_{3} \mathrm{CO}_{2}\right)_{2} \cdot 3 \mathrm{H}_{2} \mathrm{O}, \mathrm{PbCl}_{2}$, and $\mathrm{CH}_{3} \mathrm{NH}_{3} \mathrm{I}$ to address this. We obtained pinhole-free, highly crystallized perovskite films using a one-step spin-coating method followed by $10 \mathrm{~min}$ thermal annealing. The high quality of the perovskite film enables us to demonstrate a $4 \mathrm{~cm}^{2}$ aperture area perovskite module (geometrical fill factor 91\%) with a PCE of $13.6 \%$, which is the highest value reported so far. Our approach is compatible with up-scalable deposition techniques, and thus paves the way for large-scale fabrication of highly efficient perovskite modules.

Perovskite solar cells have been intensively investigated in recent years, resulting in a significant technological and scientific progress. So far, the highest certified power conversion efficiency (PCE) of perovskite thin-film solar cells surpassed 20\%, approaching the record PCEs of commercialized thin-film technologies based on CIGS or CdTe. $\frac{1,2}{}$ However, most high PCEs of perovskite solar cells are recorded on small areas, typically around $0.1 \mathrm{~cm}^{2}$. The PCEs of large area perovskite solar cells, especially modules, still lag behind those of small area devices. .34

One of the key challenges for up-scaling perovskite solar cells is the fabrication of pinhole-free, uniform perovskite films on large areas with high reproducibility: using scalable deposition techniques such as blade-coating and other roll-to-roll applicable processes. In the early stage of perovskite solar cell development, non-uniformity of the solution processed perovskite films often resulted in small area devices with a large deviation of PCEs, making histograms necessary for a thorough reporting. $\stackrel{5-8}{ }$ As a consequence, considerable research on the development of new fabrication approaches of perovskite films is being conducted to gain control of the morphology and crystallization. $\frac{2,3,9-18}{2}$ For example, the PCE and reproducibility of small area devices have been remarkably boosted by widespread use of two methods: the two-step spin-coating method with antisolvent washing, and the $\mathrm{PbI}_{2}$ seeded two-step method. $\frac{12,14}{}$ However, the up-scaling of these two processes in linear coating techniques remains questionable, since both methods increase the complexity of processing. Therefore, one-step fabricated pinhole-free perovskite films with high crystallinity still remain desirable for up-scaling perovskite solar cells.

Despite the challenges mentioned above, perovskite solar modules have been presented with active area PCEs up to $13 \%$, which is an important step towards the commercialization of perovskite solar cells. $\frac{19-24}{}$ However, there is a lack of data on the tracking of the maximum power output for perovskite solar modules, which has proven to be essential, considering the hysteresis of perovskite solar cells. $\stackrel{25}{ }$ Moreover, there are still limited reports of perovskite solar modules with high aperture area PCEs due to the reported low geometrical fill factors (the ratio of the active area to the aperture 
area). In this paper, we focus on the development of photoactive layers for modules with a high aperture PCE. We demonstrate the fabrication of pinhole-free perovskite films with high crystallinity, resulting in an aperture PCE of $13.6 \%$ in a planar junction perovskite solar module with an area of $4 \mathrm{~cm}^{2}$. The module shows a geometrical fill factor of $91 \%$, from which an active area PCE of $14.9 \%$ can be calculated. Moreover, it also shows an aperture PCE of $12.6 \%$ (active area PCE of $13.8 \%$ ) after operation at maximum power point (MPP) for $5 \mathrm{~min}$.

The module is composed of 4 serial-connected sub-cells of $1 \mathrm{~cm}^{2}$ aperture area each (Fig. 1a). The sub-cells are combined by a standard serial interconnection geometry with three patterning steps (Fig. 1b), which leads to a photovoltaic dead spacing of around $0.43 \mathrm{~mm}$ between adjacent active areas of $4.57 \mathrm{~mm}$ width (Fig. S1, ESI \pm ). This ensures a geometrical fill factor of $91 \%$, combined with a minimized power loss induced by the sheet resistance of the transparent contacts. The stack layout of the devices is illustrated in a scanning electron microscope (SEM) cross section image (Fig. 1c). Starting from an ITO coated glass substrate, $\mathrm{TiO}_{2}$ was deposited at low temperature by reactive electron beam evaporation to form the electron transport layer, without further treatments. $\frac{26}{2}$ The active layer, a homogeneous $\mathrm{CH} 3 \mathrm{NH}_{3} \mathrm{PbI}_{3-x} \mathrm{Cl}_{x}$ film, was fabricated using a one-step spincoating process followed by a $10 \mathrm{~min}$ annealing step at $130{ }^{\circ} \mathrm{C}$. A short annealing time is preferable for large-scale fabrication of perovskite solar cells. $\frac{8,27}{1}$ To complete the devices, doped 2,2',7,7'tetrakis $\left(N, N\right.$-di- $p$-methoxyphenylamine) $9,9^{\prime}$-spirobifluorene (Spiro-MeOTAD) and Au were used as the hole transport layer and the top electrode, respectively.

(a)

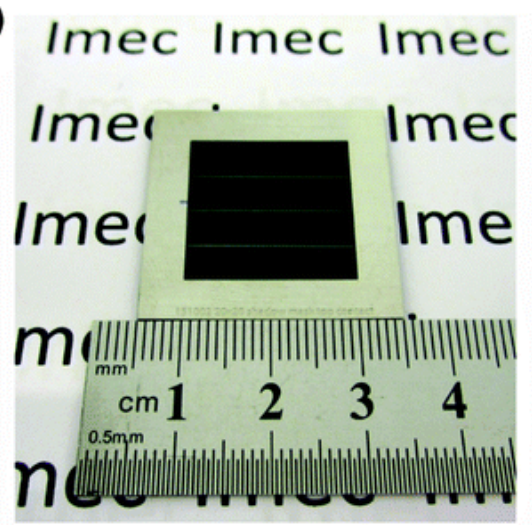

(b) $A$

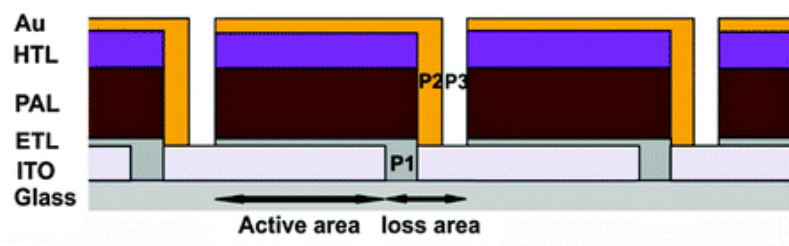

(c)

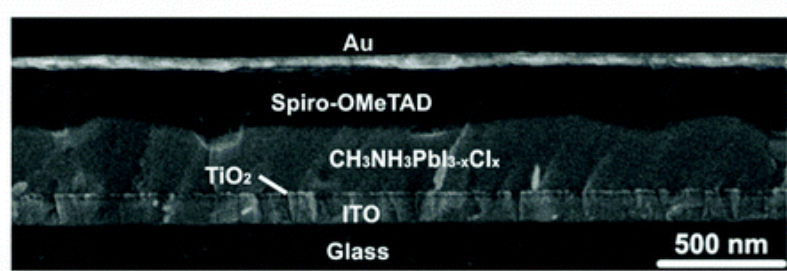

Fig. 1 (a) Photograph of the backside of the perovskite module consisting of 4 sub-cells with a total aperture area of $4 \mathrm{~cm}^{2}$. (b) Scheme of the interconnection of the sub-cells in the perovskite thin-film solar module with the patterning of the ITO bottom contact (P1), the series connection of adjacent cells (P2) and the Au top contact patterning (P3). ETL: electron transport layer; PAL: perovskite active layer; HTL: hole transport layer. (c) Cross-section SEM image showing the actual layer structure of a device. 
In order to fabricate efficient modules, compact and pinhole-free perovskite layers with high crystallinity are of utmost importance. To achieve this, we developed a new precursor combination including $\mathrm{Pb}\left(\mathrm{CH}_{3} \mathrm{CO}_{2}\right)_{2} \cdot 3 \mathrm{H}_{2} \mathrm{O}, \mathrm{PbCl}_{2}$ and $\mathrm{CH}_{3} \mathrm{NH}_{3} \mathrm{I}$ for a one-step process, in which the mole ratio of $\mathrm{Pb}$ and $\mathrm{CH}_{3} \mathrm{NH}_{3} \mathrm{I}$ is kept constant to $1: 3$. The mixture of $\mathrm{Pb}\left(\mathrm{CH}_{3} \mathrm{CO}_{2}\right)_{2} \cdot 3 \mathrm{H}_{2} \mathrm{O}$ and $\mathrm{PbCl}_{2}$ in our method combines the advantages of both lead sources, namely, fast crystallization and better perovskite film morphology. On one hand, $\mathrm{Pb}\left(\mathrm{CH}_{3} \mathrm{CO}_{2}\right)_{2} \cdot 3 \mathrm{H}_{2} \mathrm{O}$ as a lead source for perovskite film formation ensures smooth perovskite layers in a short annealing time, $\underline{28}$ even though the fast crystallization process leads to perovskite crystals with a small grain size. On the other hand, the incorporation of chlorine using $\mathrm{PbCl}_{2}$ or $\mathrm{CH}_{3} \mathrm{NH}_{3} \mathrm{Cl}$ in the $\mathrm{PbI}_{2}$ and $\mathrm{CH}_{3} \mathrm{NH}_{3} \mathrm{I}$ precursor system has been studied by different groups, indicating that the presence of chlorine can enhance the perovskite crystal formation and hence influence the morphology and properties of the perovskite film. $\frac{29-32}{2}$ Particularly, carrier diffusion lengths exceeding $1 \mu \mathrm{m}$ have been reported for $\mathrm{CH}_{3} \mathrm{NH}_{3} \mathrm{PbI}_{3-x} \mathrm{Cl}_{x}$ films. $\frac{33}{}$ However, the previous one-step fabrication of $\mathrm{CH}_{3} \mathrm{NH}_{3} \mathrm{PbI}_{3-x} \mathrm{Cl}_{x}$ using $\mathrm{PbCl}_{2}$ needs long annealing time, and often results in films with pinholes, which is disadvantageous for module fabrication. $\underline{28}$

In the new precursor system presented in this work, we achieved highly crystallized, pinhole-free perovskite films with $\mathrm{PbCl}_{2}$ molar fraction of around $20-30 \%$ in the lead source. Fig. 2 shows the top-view SEM images of the perovskite films made with 4 representative $\mathrm{PbCl}_{2}$ molar fractions, while SEM images for more $\mathrm{PbCl}_{2}$ fractions can be found in Fig. S2 (ESI we found that the $\mathrm{PbCl}_{2}$ fraction in the lead source has crucial impact on the crystal grain size and pinhole area of the perovskite film. The average grain size of the perovskite crystals increases with the $\mathrm{PbCl}_{2}$ fraction in the mixture (Fig. 2e, black curve). For the $\mathrm{PbCl}_{2}$-free precursor solution, the perovskite grain size is in the range of 100-300 nm with an average size of $222 \mathrm{~nm}$ (Fig. 2a), which is similar to the sizes reported in the literature. ${ }^{28}$ However, with the $\mathrm{PbCl}_{2}$ fraction being $20 \%$ in the

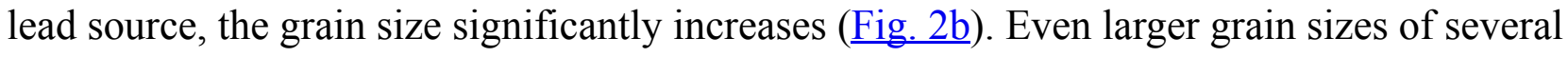
micrometers can be obtained with increasing $\mathrm{PbCl}_{2}$ fraction (Fig. $2 \mathrm{c}$ and $\mathrm{d}$ ). The larger grains result in less grain boundaries, which has been shown to increase the performance of perovskite solar cells. $\frac{34-36}{30}$ Moreover, the larger grain size also indicates improved crystallization of the perovskite film, which is confirmed by the XRD pattern (Fig. 3a). The measured films show the same perovskite structure, fingerprinted by the XRD peaks located at $14.1^{\circ}, 28.4^{\circ}$, and $43.2^{\circ}$. Those peaks can be assigned to the (110), (220) and (330) facets of $\mathrm{CH}_{3} \mathrm{NH}_{3} \mathrm{PbI}_{3-x} \mathrm{Cl}_{x}$, respectively. The intensity of the XRD peaks related to the perovskite structure increases together with the $\mathrm{PbCl}_{2}$ fraction, consistent with the SEM results. 

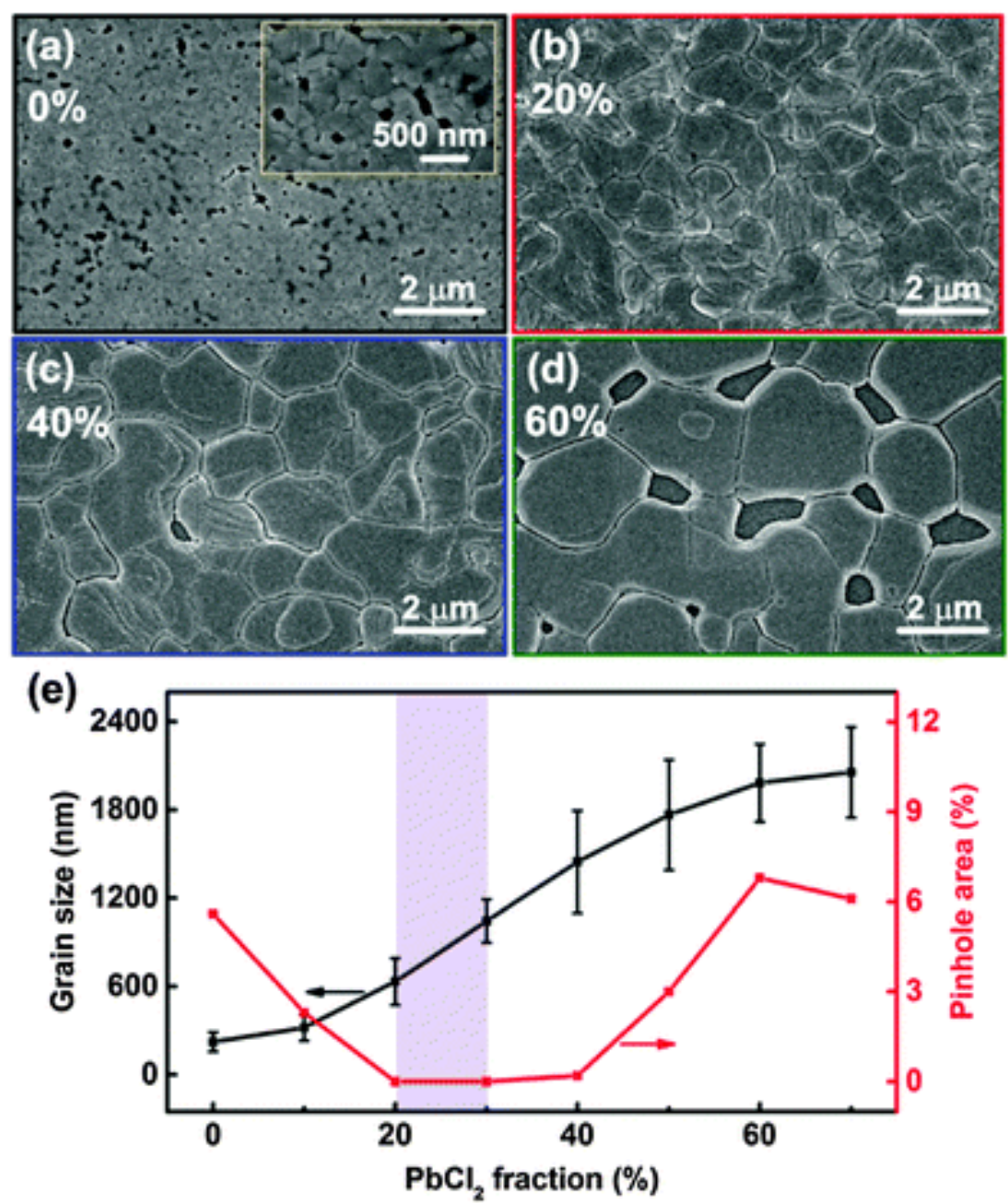

Fig. 2 Top-view SEM images of perovskite films made with representative $\mathrm{PbCl}_{2}$ molar fractions in the mixed lead source: (a) $0 \%$; (b) $20 \%$; (c) 40\%; and (d) 60\%. (e) The crystal grain size and pinhole area in the perovskite films as a function of $\mathrm{PbCl}_{2}$ fraction: calculated from the SEM images shown in Fig. S1 (ESI area indicates the $\mathrm{PbCl}_{2}$ fraction region for pinhole-free perovskite films. The average grain size is calculated using an intercept method based on the ASTM E112 standard. 

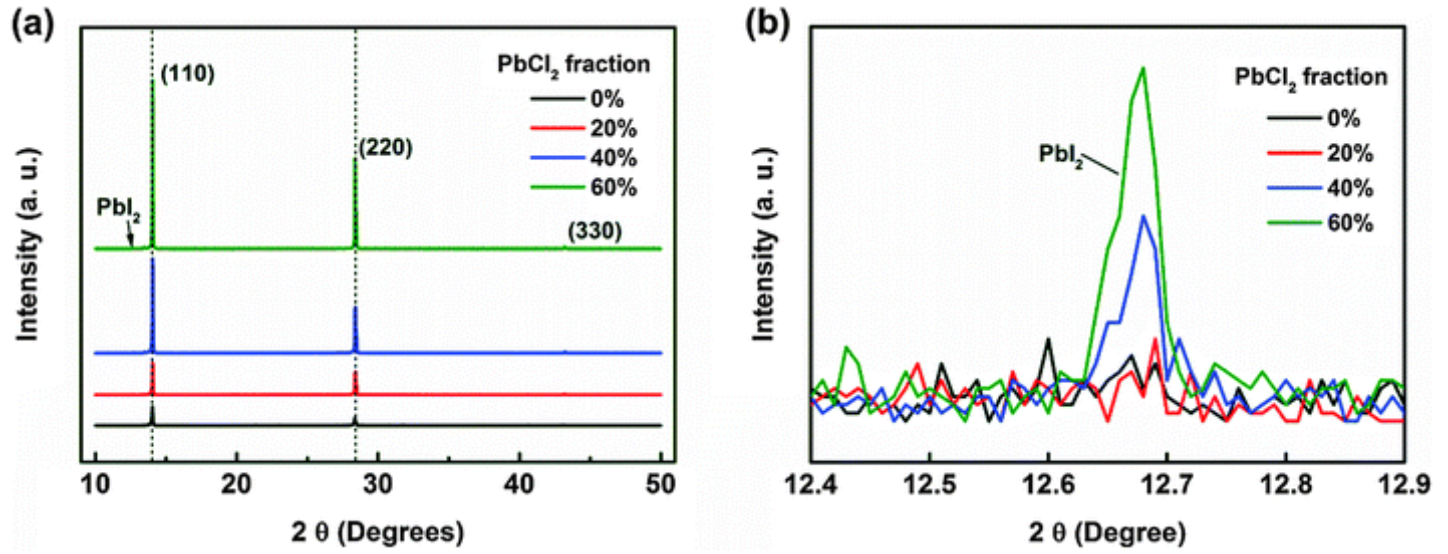

Fig. 3 XRD pattern of the perovskite films made with different $\mathrm{PbCl}_{2}$ molar fractions in the mixed lead sources: (a) full scan from $10^{\circ}$ to $50^{\circ}$; (b) zoomed-in pattern of the XRD curves shown in (a) at the diffraction angle between $12.4^{\circ}$ and $12.9^{\circ}$. The XRD peak at $12.67^{\circ}$ can be assigned to $\mathrm{PbI}_{2}$. $\underline{12}$

The $\mathrm{PbCl}_{2}$ fraction in the mixed lead source also influences the pinhole area in the perovskite film (Fig. 2e, red curve). The pinhole area first decreases with an increase in $\mathrm{PbCl}_{2}$ fraction, and pinhole free films are obtained at the $\mathrm{PbCl}_{2}$ fraction between $20 \%$ and $30 \%$. However, the incorporation of a high $\mathrm{PbCl}_{2}$ fraction in the mixed lead source results in the appearance of large pinholes and cracks in the perovskite films (Fig. 2c and d). This is probably caused by the mechanical stress induced due to the large and fast crystal growth in the perovskite film during annealing. Therefore, although a high $\mathrm{PbCl}_{2}$ fraction of $40 \%$ or $60 \%$ can lead to large crystals, these cracks and pinholes will reduce the shunt resistance of perovskite solar modules and are detrimental for module fabrication. Moreover, the zoomed-in XRD pattern (Fig. 3b) indicates diffraction peaks assigned to $\mathrm{PbI}_{2}$ for the samples fabricated with $\mathrm{PbCl}_{2}$ fractions of $40 \%$ and $60 \%$. Previous research has shown that $\mathrm{CH}_{3} \mathrm{NH}_{3} \mathrm{PbI}_{3-x} \mathrm{Cl}_{x}$ made from $\mathrm{PbCl}_{2}$ tended to degrade into $\mathrm{PbI}_{2}$ under high temperature thermal annealing. $\frac{37}{}$ The results in Fig. $3 \mathrm{~b}$ imply that the perovskite films made from relatively low $\mathrm{PbCl}_{2}$ fractions are thermally more stable when annealed at $130{ }^{\circ} \mathrm{C}$. Therefore, we conclude from the above SEM and XRD characterizations that the new precursor system with a $\mathrm{PbCl}_{2}$ molar fraction of around $20-30 \%$ as part of the lead source is likely to be the most promising precursor composition to fabricate high-quality perovskite films suitable for module fabrication.

The advantages of the optimized new precursor combination to synthesize $\mathrm{CH}_{3} \mathrm{NH}_{3} \mathrm{PbI}_{3-x} \mathrm{Cl}_{x}$ films are screened first in small area devices. Fig. 4a compares the photovoltaic parameters of the devices using perovskite films made from the representative $\mathrm{PbCl}_{2}$ fractions of $0 \%, 20 \%, 40 \%$, and $60 \%$. The evolution of the device performance is consistent with the trends observed from SEM and XRD data. Compared to the devices made from pure $\mathrm{Pb}\left(\mathrm{CH}_{3} \mathrm{CO}_{2}\right)_{2} \cdot 3 \mathrm{H}_{2} \mathrm{O}$ as the lead source, all the 
photovoltaic parameters increase for devices using the mixed lead source with the $\mathrm{PbCl}_{2}$ fraction of $20 \%$, due to the improved morphology and crystallinity. However, with the $\mathrm{PbCl}_{2}$ fraction increased to $40 \%$ and $60 \%$, the device performance continues to decrease, due to the cracks and pinholes in the perovskite films.

(a)

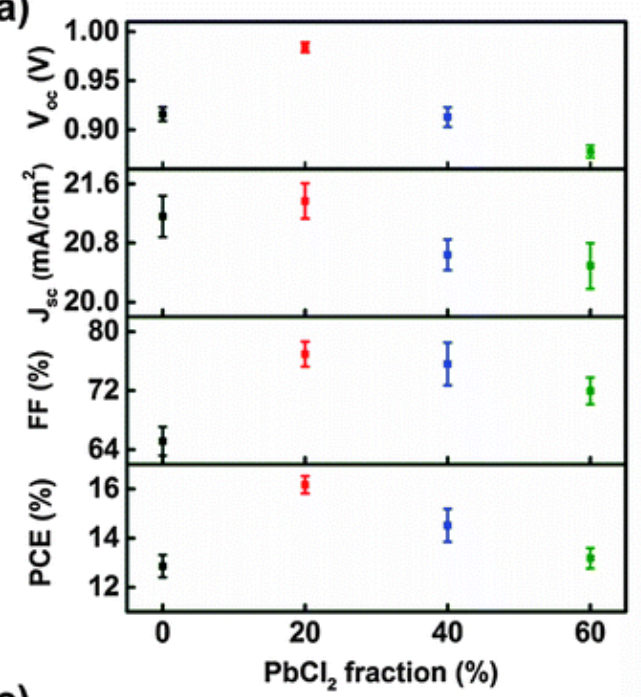

(c)

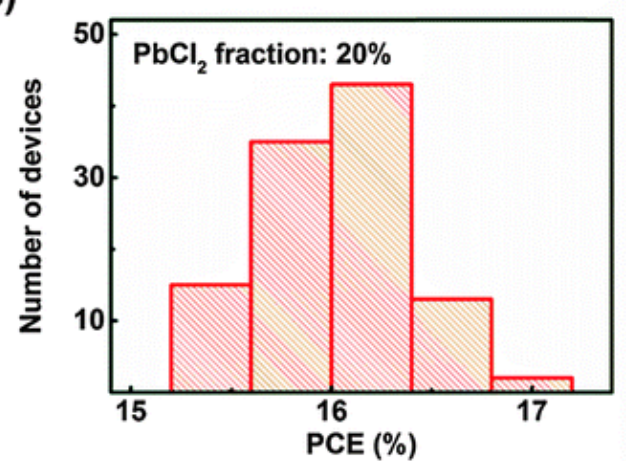

(b)

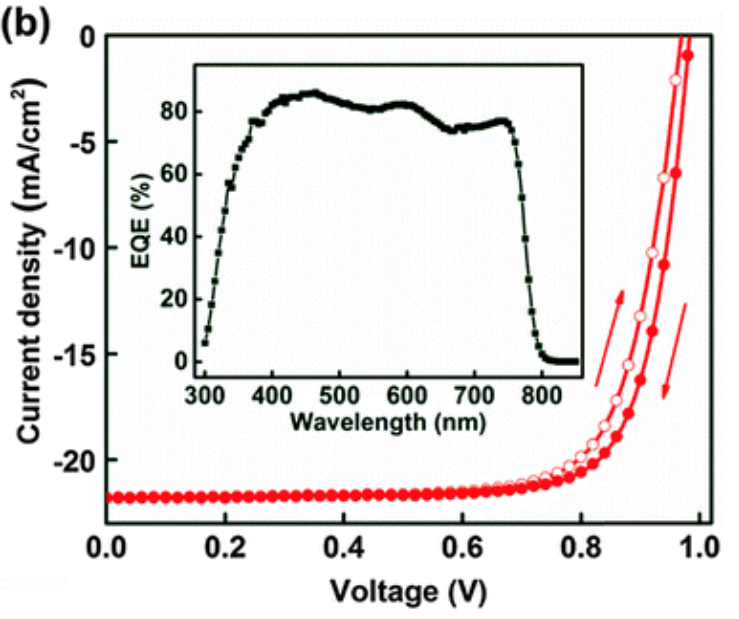

(d)

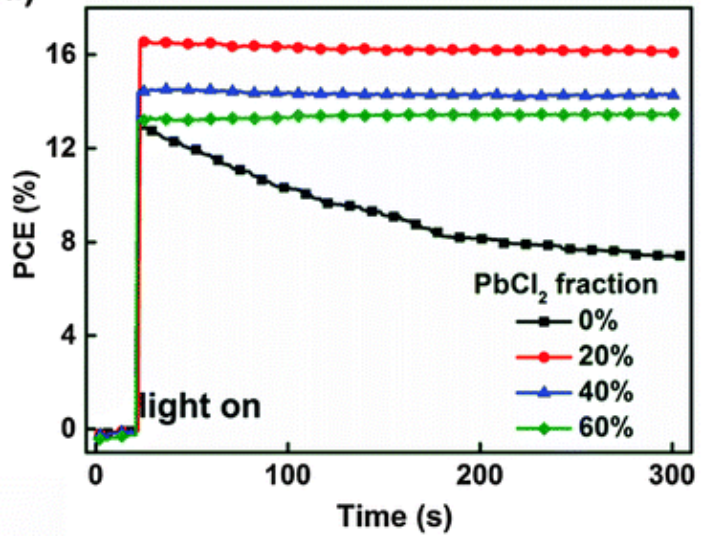

Fig. 4 (a) The average photovoltaic parameters of small area devices made with different $\mathrm{PbCl}_{2}$ fractions in the lead source: data calculated from 12 devices on the same substrate for each composition. (b) The $J-V$ curves scanned in different voltage sweep directions on a typical device using the mixed lead source with $\mathrm{PbCl}_{2}$ fraction of $20 \%$ : the scan directions are indicated by the arrows; the inset is the corresponding EQE curve. (c) A PCE histogram of 108 devices using the mixed lead source with $\mathrm{PbCl}_{2}$ fraction of $20 \%$, showing an average performance of $16.0 \% \pm 0.4 \%$. (d) The evolutions of the PCE values over time, measured by an MPP tracker: the initial data of the devices are given in Table S1 (ESI亡). 
Fig. 4b shows the $J-V$ curves scanned from different directions and the corresponding external quantum efficiency (EQE) of a typical device using the mixed lead source with a $\mathrm{PbCl}_{2}$ fraction of $20 \%$. When scanned from forward biased to reverse biased, it shows a short-circuit current density $\left(J_{\mathrm{sc}}\right)$ of $21.8 \mathrm{~mA} \mathrm{~cm}^{-2}$, open-circuit voltage $\left(V_{\mathrm{oc}}\right)$ of $0.98 \mathrm{~V}$, fill factor $(\mathrm{FF})$ of $78 \%$, and thus resulting in a PCE of $16.7 \%$. When scanned from the opposite direction, it gives a $J_{\mathrm{sc}}$ of $21.8 \mathrm{~mA} \mathrm{~cm}$ ${ }^{-2}, V_{\mathrm{oc}}$ of $0.97 \mathrm{~V}$, FF of $75 \%$, and thus a PCE of $16.0 \%$, which is slightly lower. The current density calculated from the EQE equals to $20.2 \mathrm{~mA} \mathrm{~cm}^{-2}$, resulting in around $7 \%$ mismatch as compared to the value obtained from the $J-V$ scan. By virtue of the high uniformity and reproducibility of the perovskite film, the small area devices made using the optimized method show an average PCE of $16.0 \% \pm 0.3 \%$, calculated from 108 devices ( $\underline{\text { Fig. } 4 \mathrm{c}})$. This small variation in device performance indicates the high level of uniformity, which is desired for the processing of perovskite solar modules.

Due to the hysteresis of perovskite solar cells, we also report the PCE evolution of the devices during a continuous operation at the maximum power point for 5 min under 1 sun conditions (Fig. $\underline{4 \mathrm{~d}})$. The detailed photovoltaic parameters obtained from the $J-V$ scan can be found in Table S1 (ESI \pm ). The device made with pure $\mathrm{Pb}\left(\mathrm{CH}_{3} \mathrm{CO}_{2}\right)_{2} \cdot 3 \mathrm{H}_{2} \mathrm{O}$ as the lead source shows a fast degradation resulting in an efficiency of $7.4 \%$ after $5 \mathrm{~min}$, while the PCE values of the devices using a mixture of $\mathrm{Pb}\left(\mathrm{CH}_{3} \mathrm{CO}_{2}\right)_{2} \cdot 3 \mathrm{H}_{2} \mathrm{O}$ and $\mathrm{PbCl}_{2}$ are rather constant during the recorded time frame. Here, the device with the optimized $\mathrm{PbCl}_{2}$ fraction of $20 \%$ shows the highest PCE of $16.1 \%$ after 5 min of continuous illumination. Considering that the same device structure, electron transport layer, and hole transport layers are used for all the devices, we relate the behavior under maximum power point tracking to the crystal grain size of the perovskite films. This assumption is supported by a recent report on the inverse relationship between perovskite crystal sizes and hysteresis. $\frac{36,38}{}$ We also note that the presence of $\mathrm{Cl}^{-}$may have a beneficial impact on reducing non-radiative recombination sites in the perovskite films, $\underline{39}$ which are likely to also contribute to the hysteresis in the $J-V$ curves. $\underline{40}$

From all the results shown above, we can confirm that pinhole-free and uniform perovskite films with good electrical properties are achieved, and therefore we fabricated perovskite modules using the optimal precursor combination. Fig. 5a shows the equivalent $J-V$ curve for a perovskite solar module, using the $1 \mathrm{~cm}^{2}$ aperture area of a sub-cell for the derivation of the current density and the number of sub-cells for the voltage determination. When scanned from the forward bias to reverse biased, the module exhibits a $J_{\mathrm{sc}}$ of $19.9 \mathrm{~mA} \mathrm{~cm}-2, V_{\mathrm{oc}}$ of $0.91 \mathrm{~V}$, FF of $75 \%$, and thus PCE of $13.6 \%$. When scanned from the opposite direction, the $J_{\mathrm{sc}}$ and $V_{\mathrm{oc}}$ remain the same, but the FF decreases to $69 \%$, resulting in a lower PCE of $12.5 \%$. Compared to a typical $0.13 \mathrm{~cm}^{2}$ small area device, the module shows a $9 \%$ lower $J_{\text {sc }}$ and a $7 \%$ reduced $V_{\text {oc }}$. The loss in $J_{\text {sc }}$ is mainly related to the active area lost due to the sub-cell interconnections, which is around $9 \%$ of the aperture area. The reduced $V_{\text {oc }}$ can be the result of imperfections in the interconnections and small shunts. Considering the hysteresis, we show the evolution of the PCE and the change of MPP over 5 min of 
continuous illumination (Fig. 5b). The module shows a nearly constant PCE within the measurement time, giving a PCE of $12.6 \%$ after 5 min. While only a small change is observed in the module efficiency during the MPP tracking, the voltage of the MPP is dropped from $2.8 \mathrm{~V}$ to $2.71 \mathrm{~V}$ for the whole module. On one hand, such a drop in MPP voltage can be related to the overestimated initial set point obtained from the $J-V$ scan. On the other hand, the light soaking and the temperature of the module during the long-time measurement also have effects on the module MPP.
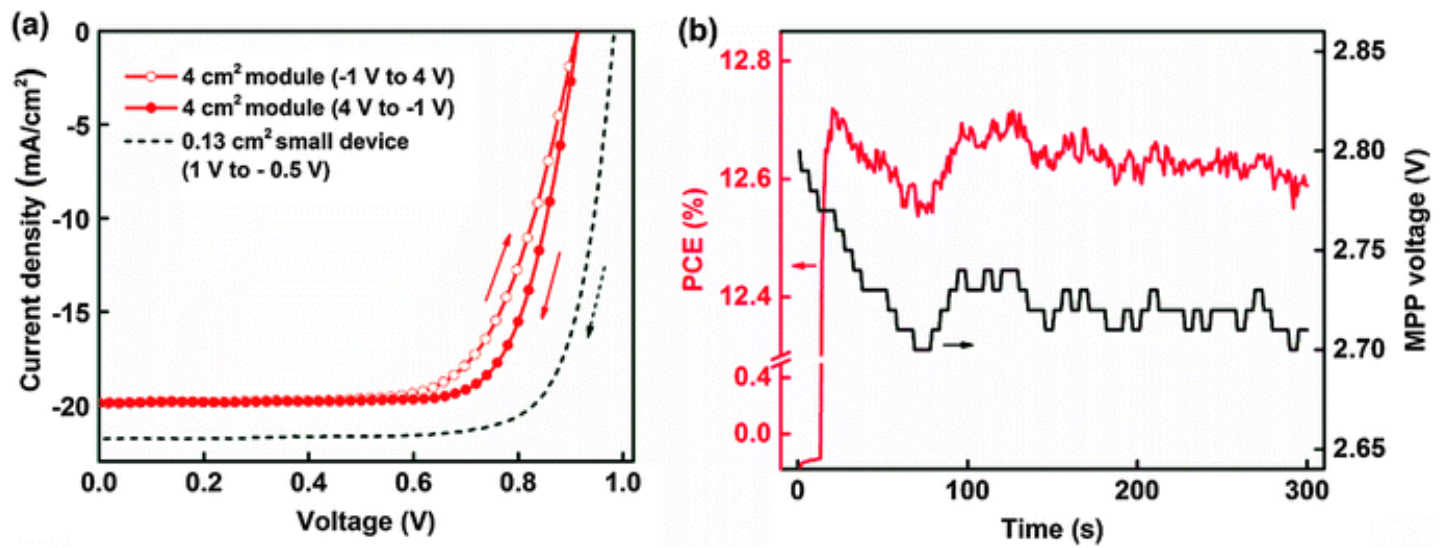

Fig. 5 (a) Comparison of the equivalent $J-V$ curve of the $4 \mathrm{~cm}^{2}$ perovskite solar module with a typical $0.13 \mathrm{~cm}^{2}$ small area device. The arrows indicate the $J-V$ scan direction. (b) PCE and MPP voltage of the module as a function of operation time, measured by a MPP tracker. The initial set point for MPP is $2.8 \mathrm{~V}$.

In summary, we have presented a $4 \mathrm{~cm}^{2}$ aperture area perovskite module with a PCE of 13.6\% from the $J-V$ scan and $12.6 \%$ after 5 min of MPP tracking. The module has a geometrical fill factor of $91 \%$, giving an active area PCE of $14.9 \%$. The high PCE is based on a highly crystallized pinhole-free perovskite film, which can be fabricated using a new precursor combination containing $\mathrm{Pb}\left(\mathrm{CH}_{3} \mathrm{CO}_{2}\right)_{2} \cdot 3 \mathrm{H}_{2} \mathrm{O}, \mathrm{PbCl}_{2}$, and $\mathrm{CH}_{3} \mathrm{NH}_{3} \mathrm{I}$. Such a composite lead source combines the advantages of both $\mathrm{Pb}\left(\mathrm{CH}_{3} \mathrm{CO}_{2}\right)_{2} \cdot 3 \mathrm{H}_{2} \mathrm{O}$ and $\mathrm{PbCl}_{2}$ : the former enables a fast crystallization time of within 10 min, while the latter leads to crystal grains of micrometer scale. The optimal $\mathrm{PbCl}_{2}$ molar fraction in the lead source composition is around 20-30\%. Our one-step fabrication approach is compatible with up-scalable deposition techniques, and thus paves the way for large-scale fabrication of highly efficient perovskite modules.

\section{Acknowledgements}

The authors would like to thank Yi Li for the SEM measurement, Jeffrey G. Tait for calculating the pinhole areas from the SEM images of perovskite films. This work was supported in part by the Flemish Government: Department of Economics, Science and Innovation. The work of U. W. Paetzold was supported by the German Academic Exchange Service. The authors declare no 
competing financial interests.

\section{Notes and references}

1. M. A. Green, K. Emery, Y. Hishikawa, W. Warta and E. D. Dunlop, Prog. Photovoltaics Res. Appl., 2015, 23, 1-9 CrossRef 2 .

2. W. S. Yang, J. H. Noh, N. J. Jeon, Y. C. Kim, S. Ryu, J. Seo and S. Il Seok, Science, 2015, 348, 1234-1237 CrossRef CAS PubMed 2.

3. M. Yang, Y. Zhou, Y. Zeng, C.-S. Jiang, N. P. Padture and K. Zhu, Adv. Mater., 2015, 27, 6363-6370 CrossRef CAS PubMed 2.

4. W. Chen, Y. Wu, Y. Yue, J. Liu, W. Zhang, X. Yang, H. Chen, E. Bi, I. Ashraful, M. Grätzel and L. Han, Science, 2015, 350, 944-948 CrossRef CAS PubMed a .

5. D. Liu and T. L. Kelly, Nat. Photonics, 2013, 8, 133-138 CrossRef a .

6. J. H. Heo, S. H. Im, J. H. Noh, T. N. Mandal, C.-S. Lim, J. A. Chang, Y. H. Lee, H. Kim, A. Sarkar, M. K. Nazeeruddin, M. Grätzel and S. Il Seok, Nat. Photonics, 2013, 7, 486491 CrossRef CAS 2.

7. G. E. Eperon, V. M. Burlakov, P. Docampo, A. Goriely and H. J. Snaith, Adv. Funct. Mater., 2014, 24, 151-157 CrossRef CAS .

8. W. Qiu, M. Buffière, G. Brammertz, U. W. Paetzold, L. Froyen, P. Heremans and D. Cheyns, Org. Electron., 2015, 26, 30-35 CrossRef CAS .

9. Q. Chen, H. Zhou, Z. Hong, S. Luo, H. Duan, H. Wang, Y. Liu, G. Li and Y. Yang, J. Am. Chem. Soc., 2013, 136, 622-625 CrossRef PubMed .

10. M. Liu, M. B. Johnston and H. J. Snaith, Nature, 2013, 501, 395-398 CrossRef CAS PubMed .

11. J. Burschka, N. Pellet, S.-J. Moon, R. Humphry-Baker, P. Gao, M. K. Nazeeruddin and M. Grätzel, Nature, 2013, 499, 316-319 CrossRef CAS PubMed .

12. N. J. Jeon, J. H. Noh, Y. C. Kim, W. S. Yang, S. Ryu and S. Il Seok, Nat. Mater., 2014, 13, 17 Search PubMed 2.

13. W. Nie, H. Tsai, R. Asadpour, J. Blancon, A. J. Neukirch, G. Gupta, J. J. Crochet, M. Chhowalla, S. Tretiak, M. A. Alam, H. Wang and A. D. Mohite, Science, 2014, 347, 522525 CrossRef PubMed 2.

14. Z. Xiao, C. Bi, Y. Shao, Q. Dong, Q. Wang, Y. Yuan, C. Wang, Y. Gao and J. Huang, Energy Environ. Sci., 2014, 7, 2619-2623 CAS *

15. J. H. Heo, H. J. Han, D. Kim, T. K. Ahn and S. H. Im, Energy Environ. Sci., 2015, 8, $1602-$ 1608 CAS 2.

16. T. Zhang, M. Yang, Y. Zhao and K. Zhu, Nano Lett., 2015, 15, 39593963 CrossRef CAS PubMed 2.

17. W. Li, J. Fan, J. Li, Y. Mai and L. Wang, J. Am. Chem. Soc., 2015, 137, 1039910405 CrossRef CAS PubMed 2.

18. N. Ahn, D.-Y. Son, I.-H. Jang, S. M. Kang, M. Choi and N.-G. Park, J. Am. Chem. Soc., 2015, 137, 8696-8699 CrossRef CAS PubMed 2. 
19. S.-J. Moon, J.-H. Yum, L. Lofgren, A. Walter, L. Sansonnens, M. Benkhaira, S. Nicolay, J. Bailat and C. Ballif, IEEE J. Photovoltaics, 2015, 5, 1087-1092 CrossRef • .

20. F. Matteocci, L. Cinà, F. Di Giacomo, S. Razza, A. L. Palma, A. Guidobaldi, A. D'Epifanio, S. Licoccia, T. M. Brown, A. Reale and A. Di Carlo, Prog. Photovoltaics Res. Appl., 2014 DOI: $10.1002 /$ pip.2557 2 .

21. F. Matteocci, S. Razza, F. Di Giacomo, S. Casaluci, G. Mincuzzi, T. M. Brown, A. D'Epifanio, S. Licoccia and A. Di Carlo, Phys. Chem. Chem. Phys., 2014, 16, 3918-3923 RSC

22. S. Razza, F. Di Giacomo, F. Matteocci, L. Cinà, A. L. Palma, S. Casaluci, P. Cameron, A. D'Epifanio, S. Licoccia, A. Reale, T. M. Brown and A. Di Carlo, J. Power Sources, 2015, 277, 286-291 CrossRef CAS 2.

23. F. Di Giacomo, V. Zardetto, A. D. Epifanio, S. Pescetelli, F. Matteocci, S. Razza, A. Di Carlo, S. Licoccia, W. M. M. Kessels, M. Creatore, T. M. Brown, F. Di Giacomo, V. Zardetto, A. D'Epifanio, S. Pescetelli, F. Matteocci, S. Razza, A. Di Carlo, S. Licoccia, W. M. M. Kessels, M. Creatore and T. M. Brown, Adv. Energy Mater., 2015 DOI: $10.1002 /$ aenm.201401808 .

24. J. Seo, S. Park, Y. Chan Kim, N. J. Jeon, J. H. Noh, S. C. Yoon, S. Il Seok and P. S. Cells, Energy Environ. Sci., 2014, 7, 2642-2646 CAS 2.

25. H. J. Snaith, A. Abate, J. M. Ball, G. E. Eperon, T. Leijtens, N. K. Noel, S. D. Stranks, J. T. W. Wang, K. Wojciechowski and W. Zhang, J. Phys. Chem. Lett., 2014, 5, 15111515 CrossRef CAS PubMed 2.

26. W. Qiu, U. W. Paetzold, R. Gehlhaar, V. Smirnov, H.-G. Boyen, J. G. Tait, B. Conings, W. Zhang, C. B. Nielsen, I. McCulloch, L. Froyen, P. Heremans and D. Cheyns, J. Mater. Chem. $A, 2015,3,22824-22829$ CAS 2.

27. U. W. Paetzold, W. Qiu, F. Finger, J. Poortmans and D. Cheyns, Appl. Phys. Lett., 2015, 106, 173101 CrossRef 2.

28. W. Zhang, M. Saliba, D. T. Moore, S. K. Pathak, M. T. Hörantner, T. Stergiopoulos, S. D. Stranks, G. E. Eperon, J. A. Alexander-Webber, A. Abate, A. Sadhanala, S. Yao, Y. Chen, R. H. Friend, L. A. Estroff, U. Wiesner and H. J. Snaith, Nat. Commun., 2015, 6, 6142 CrossRef PubMed 3.

29. S. Colella, E. Mosconi, P. Fedeli, A. Listorti, F. Orlandi, P. Ferro, T. Besagni, A. Rizzo, G. Calestani, G. Gigli, F. De Angelis, R. Mosca and F. Gazza, Chem. Mater., 2013, 25, 46134618 CrossRef 2.

30. Y. Tidhar, E. Edri, H. Weissman, D. Zohar, G. Hodes, D. Cahen, B. Rybtchinski and S. Kirmayer, J. Am. Chem. Soc., 2014, 136, 13249-13256 CrossRef CAS PubMed \& .

31. Q. Chen, H. Zhou, Y. Fang, A. Z. Stieg, T.-B. Song, H.-H. Wang, X. Xu, Y. Liu, S. Lu, J. You, P. Sun, J. McKay, M. S. Goorsky and Y. Yang, Nat. Commun., 2015, 6, 7269 CrossRef CAS PubMed 2.

32. H. Yu, F. Wang, F. Xie, W. Li, J. Chen and N. Zhao, Adv. Funct. Mater, 2014, 24, 71027108 CAS

33. S. D. Stranks, G. E. Eperon, G. Grancini, C. Menelaou, M. J. P. Alcocer, T. Leijtens, L. M. Herz, A. Petrozza and H. J. Snaith, Science, 2013, 342, 341-344 CrossRef CAS PubMed . 
34. C. Bi, Q. Wang, Y. Shao, Y. Yuan, Z. Xiao and J. Huang, Nat. Commun., 2015, 6, 7747 CrossRef CAS PubMed 2.

35. Z. Xiao, Q. Dong, C. Bi, Y. Shao, Y. Yuan and J. Huang, Adv. Mater, 2014, 26, 65036509 CrossRef CAS PubMed 2.

36. J.-H. Im, I.-H. Jang, N. Pellet, M. Grätzel and N.-G. Park, Nat. Nanotechnol., 2014, 9, 927932 CrossRef CAS PubMed 2.

37. K. W. Tan, D. T. Moore, M. Saliba, H. Sai, L. A. Estroff, T. Hanrath, H. J. Snaith and U. Wiesner, ACS Nano, 2015, 4730-4739 Search PubMed 3.

38. H. S. Kim and N.-G. Park, J. Phys. Chem. Lett., 2014, 5, 2927-2934 CrossRef CAS PubMed .

39. D. W. de Quilettes, S. M. Vorpahl, S. D. Stranks, H. Nagaoka, G. E. Eperon, M. E. Ziffer, H. J. Snaith and D. S. Ginger, Science, 2015, 348, 683-686 CrossRef CAS PubMed a .

40. S. van Reenen, M. Kemerink and H. J. Snaith, J. Phys. Chem. Lett., 2015, 6, 38083814 CrossRef CAS PubMed 2 .

\section{Footnote}

$\dagger$ Electronic supplementary information (ESI) available. See DOI: $\underline{\text { 10.1039/c5ee03703d }}$

This journal is (C) The Royal Society of Chemistry 2016 